\title{
Dilemma and Development: Research on Supervision of Social Work Practice
}

\author{
Jinfeng $\mathrm{Ma}^{1 *}$,Lixia Liang ${ }^{2}, \mathrm{Yu} \mathrm{Han}^{3}$ \\ ${ }^{1,2,3}$ School of Political Science and Law University of Jinan,Shandong Province, China,250022 \\ *Corresponding author. Email:1261542528@qq.com
}

\begin{abstract}
:
Social work is a self-help service activity. The social work major is an application major with strong practicality. Internship supervision plays an important role in promoting the development of the social work major. At present, social work internship supervision is faced with the dilemma of the unbalanced development of theory and practice, the unclear role positioning of internship supervision, the formalization of internship supervision mode, and the low degree of professionalization of internship supervision. Therefore, in order to promote the development of internship supervision of social work majors, the development path of internship supervision should be further improved.
\end{abstract}

Keywords: Social Work, Internship Supervision, Path Research

\section{INTRODUCTION}

The salient feature of social work is helping others to help themselves. Obviously, the social work profession requires high practicality and applicability [1]. Therefore, for the social work major, professional internship is extremely important for the training system and discipline construction. The American Social Work Encyclopedia defines supervision as:" Supervision is a traditional method of social work profession. Through this method, social work knowledge and skills are passed from a trained social worker to a new social worker or intern" [2]. Internship supervision is an indispensable key part of social work professional internship. In addition, internship supervision is also important in the construction and development of social work major. However, from the present point of view, my country's social work professional internship supervision still faces many difficulties, and it is urgent to make corresponding adjustments and changes to promote the further development of social work professional.

\section{DIFFICULTIES FACED BY SOCIAL WORK PROFESSIONAL INTERNSHIP SUPERVISION}

The social work major in my country started at the end of the 1980s. Compared with Western countries, it started late, and its development is not perfect. Especially in terms of internship supervision, my country still lacks a relatively complete supervision system, and the internship supervision of social work majors still faces many difficulties.

\subsection{Unbalanced Development of Theory And Practice}

Theory and practice are equally important for the development of the social work profession. However, for social work professional internship supervision, it is facing an imbalance in the development of theory and practice. Social work practice supervision is generally composed of college teacher supervision and institutional supervision. However, college teacher supervision has high theoretical literacy and insufficient practical experience, while institutional supervision has rich practical experience, but lack of theoretical literacy. For a long time, college teachers have focused on theoretical research and academic exploration, but lack in specific practice. Especially when dealing with the case of the client, teacher supervision shows high theoretical support, but lacks sufficient practical experience. Institutional supervision, because of long-term handling of specific projects, has rich practical experience and can better help students when dealing with professional practical problems. But compared with teacher supervision, institutional supervision lacks more theoretical literacy, and cannot allow students to combine practice with the theoretical knowledge learned in the classroom.

\subsection{The Role of Internship Supervision is Not Clear}

Social work professional internship supervision assumes more roles. The positioning and understanding of their roles are related to the guidance of students' professional internship and the growth of their own work. Generally speaking, internship supervisors act as managers, supporters and educators in student internships. However, in the actual internship process, the role orientation of the internship supervision is not clear, and it has played the 
role of manager and educator more, and the role of supporter has not been better reflected. In the process of student internship, teacher supervision and organization supervision are focused on formulating internship plans for students, assigning internship tasks, and guiding students to carry out internship work, lacking care and support for students, so that students have many complaints and nowhere in the internship process The complaint reduces the enthusiasm and confidence of students in the work of social workers.

\subsection{Formalization of Internship Supervision Mode}

At present, the social work professional internship supervision mode is roughly divided into three types: college teachers independent supervision, independent supervision of internship institutions, and joint supervision mode of college teachers and internship institutions [3]. For most institutions, the internship of students is jointly undertaken by the faculty supervision and institution supervision. The teacher supervision of the college is responsible for contacting the internship institutions and internship projects, making internship planning, supervising and evaluating the students' internship process. The institution supervision is mainly responsible for the arrangement of students' activities in the internship of the institution, giving professional guidance and evaluation. Generally speaking, the college has a designated internship institution for students. The college maintains a long-term cooperative relationship with the internship institution. However, in the specific operation process, due to the inconsistency of communication and pursuit of goals between the two parties, the internship has become a natural mechanical task. The responsibilities that supervisors should perform cannot be effectively put in place, and sometimes make both parties feel a pressure rather than meet professional or institutional needs.

\subsection{Low Professionalization of Internship Supervision}

The professionalization degree of social work internship supervision in my country is relatively weak, but the level and quality of internship supervision is closely related to the internship quality and final learning level of social work major students [4]. Supervisors need to have high theoretical literacy and rich practical experience. Whether it is a teacher or a full-time social worker as a supervisor, it is difficult to meet this requirement. Teachers' main energy is concentrated on school teaching and scientific research tasks, and they are only temporarily appointed or responsible for student internship work. The specific internship supervision responsibilities cannot be well connected. And the internship supervision in the institution is usually too busy with administrative work. Supervision and management are often just walking through the field, and rarely can really guide students to carry out internship work. Internship supervision with lower specialization has less help in student internships, and it is difficult for students to truly learn the work skills that social workers should possess through internships.

\section{RESEARCH ON THE DEVELOPMENT PATH OF SOCIAL WORK PROFESSIONAL SUPERVISION PRACTICE}

As far as the current situation is concerned, there are still many deficiencies in the development of social work professional internship supervision. In order to improve the internship effect of the social work major and promote the development of the social work major, it is necessary to overcome many obstacles faced by the internship supervision. Therefore, the development path of the internship supervision of the social work major is discussed.

\subsection{Cultivate Professional Internship Supervision}

A qualified internship supervisor not only requires the theoretical knowledge and practical experience of the social work major, but also needs to be in harmony with classmates to stimulate students' interest in learning and play a role as a bridge between institutions and universities [5].For college teachers to supervise, while mastering theoretical knowledge, they should participate in practical learning and accumulate rich project information. In the process of supervising students for internship, they can combine the actual situation of social workers to make student internship planning and arrangement, and give professional guidance according to the specific situation of students. College teacher supervision can use the college platform to participate in social work projects within the organization, communicate with and learn from experts with practical experience and first-line social workers. For the supervision of institutional social workers, it is necessary to regularly participate in social worker training, to reflect on and improve their practical work through theoretical study. At the same time, social work organizations should also communicate well with college experts to further enhance the theoretical level of the social work of the institutions and be able to better guide practical work.

\subsection{Adjust Internship Supervision Mode in Time}

The choice of internship supervision mode should be combined with the actual situation, and different internship supervision modes are adopted in different internship 
stages. During the internship period of low-level social work students, the college supervision teachers should be the main responsible for arranging the internship plan of the students. At the same time, they should discuss and communicate with the students to help students learn the values of social work to help others. The next step Lay a good foundation for professional internship and learning; during the period of professional internship for senior social work majors, institutional supervision should be the mainstay, and institutional supervision should guide students' professional internship, teach and guide the work skills of social workers, and cultivate The ability of students to learn and handle things autonomously.

\subsection{Create A Harmonious Internship Supervision System}

College supervision, institution supervision and students are a solid triangle system (Figure 1). The relationship between college supervisors and institutional supervisors is a partnership. Communication and consultation on student internships is aimed at enabling students to learn practical skills during internships and lay the foundation for future work positions; between college supervisors and students Teacher-student relationship, college teachers are responsible for students' internship progress and arrangement, answer doubts for students and do support work for students, evaluate students' internship process. Instructor-student relationship between the institution supervisor and students, guide and teach students work skills, help students understand the work of social workers, do well and reflect on the work content. College supervision and organization supervision form close contact with the students, and jointly promote the development of student professional internships and the professionalization of social work services.

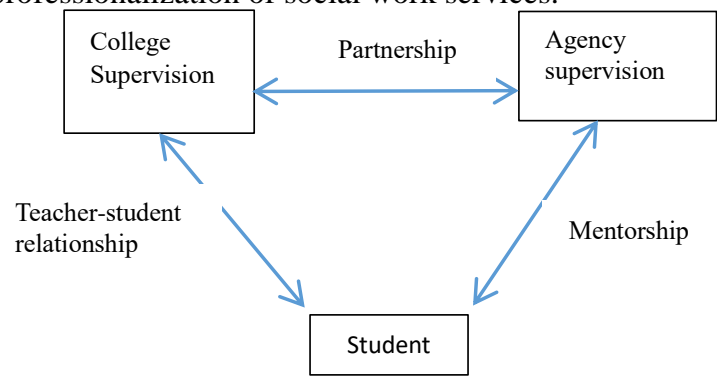

Figure 1 Triangle system

\subsection{Improve The Internship Supervision and Development System}

The training of internship supervision can take the "old and new" approach, allowing experienced internship supervision to lead young internship supervision to carry out internship work, so that the training of internship supervision can be continuous; at the same time, it can adopt the methods of visiting, training and participating in projects To give internship supervisors more learning opportunities, master theories and have rich practical experience; the promotion system for internship supervisors should be gradually improved to allow internship supervisors to achieve self-growth.

\section{SUMMARY}

Internship supervision occupies an important position in social work professional development and discipline construction. Social work professional methods and skills, as well as professional values and ethics, need to be better used in the internship process. The improvement and development of internship supervision has further promoted the training of social workers' professional talents, and also promoted the improvement of social work disciplines and majors, and improved the recognition of social work majors.Therefore, in order to promote the development of social work internship supervision, it is necessary to cultivate professional internship supervision, adjust the internship supervision mode in accordance with the actual situation, create a harmonious internship supervision relationship, and further improve the internship supervision development system.

\section{ACKNOWLEDGMENT}

This article is one of the series of achievements of the Shandong Province Undergraduate University Teaching Reform Research Project "Innovation and Practice of the "3232" Talent Training Model for Outstanding Social Workers" (Project Number: M2018X032).

\section{REFERENCES}

[1] Wang Sibin. Introduction to Social Work [M]. Beijing: Higher Education Press, 1999.

[2] Richard L. Edwards (Edi). Encyclopedia of Social Work [M]. NASW Press, 1995.

[3] Zhang Minjie, Ni Wanhong. An Analysis of Joint Supervision of Social Work Internship[J]. Social Work (Academic Edition), 2011(01): 59-62.

[4] Huang Hong, Chu Zhiwei. Analysis of the practical dilemma of social work professional internships [J]. Heilongjiang Higher Education Research, 2009(07): 34-35.

[5] Liu Binzhi, Shen Li. Reflection on Social Work Supervision: Learning to be an effective social work supervision teacher [J]. Social Work, 2006(09): 35-37. 